“C 2011 IEEE. Personal use of this material is permitted. Permission from IEEE must be obtained for all other uses, in any current or future media, including reprinting/republishing this material for advertising or promotional purposes, creating new collective works, for resale or redistribution to servers or lists, or reuse of any copyrighted component of this work in other works." 


\title{
Towards a methodological framework for designing a KaaS system
}

\author{
Eng K. Chew \\ School of Systems, Management and Leadership \\ University of Technology, Sydney \\ NSW, Australia \\ Eng.chew@uts.edu.au
}

\begin{abstract}
The paper proposes a KaaS conceptual model by using the well-known definitions of knowledge vis-à-vis information. Based on this KaaS model, using the principles of business model and service science, the paper proposes a representative classification KaaS business model types as well as a preliminary macro-methodological framework for designing commercially viable KaaS. The design emphasis is on distinctive KaaS value proposition for a chosen market segment, simple revenue mechanism, low cost structure, and agile value network that positions the focal firm strategically on the 'choke-point' in the value net which 'locks in' its customers and value partners while 'locking-out' potential or real competitors.
\end{abstract}

Keywords-KaaS, business model, service science, design methodology

\section{INTRODUCTION}

Clouds technologies are enabling new types of on-demand service such as infrastructure, platform and software as a service. Clouds are a large pool of easily usable and accessible virtualized resources, through a pay-per-use revenue method, which can be dynamically reconfigured to allow optimum resources utilization [11]. The emerging next-generation networks are also allowing telecom service providers to offer "application environment as a service" to entrepreneurial third-party service providers to, in turn, create and offer new innovative services to the market, under a variety of negotiated business models and associated service agreements [3]. These dual trends are offering entrepreneurs opportunities to extend the on-demand service models to the new "knowledge as a service" KaaS model. According to the principles of service science [12], we argue that the purpose of KaaS service is to allow clients 'pay-per-use' access to 'specialized' provider knowledge, on-demand, so as to integrate it with their own specific internal knowledge to create value for themselves (and hence the provider). This paper proposes a methodological framework for designing KaaS that co-creates value with customers. It is organized as follows. Section II reviews briefly the definitions of knowledge vis-à-vis information, and proposes a conceptual KaaS model and a typology of KaaS. Section III overviews the business model and service science principles and proposes a KaaS business model classification. From these the framework for KaaS model design is also derived and proposed in Section IV. Section V concludes the paper with a preliminary 'trialling' of the proposed framework to a case example.

\section{DEFINITIONS OF KNOWLEDGE \& KAAS}

Fahey and Prusak [5] argue knowledge is information combined with experience, context, interpretation, reflection, intuition and creativity. Information becomes knowledge once it is processed in the mind of an individual. This knowledge then becomes information again once it is articulated or communicated to others in the form of text, computer output, spoken, or written words or other means.

Grover and Davenport [7] claim knowledge processes lie somewhere between information and the firm's source of revenue, its products and services. This process can be generically represented in three sub processes: knowledge generation, knowledge codification, and knowledge transfer/realization. We use the Grover-Davenport model to define the KaaS model (Figure 1) where the product or service is the codified knowledge generated by the knowledge service provider. Knowledge is commonly distinguished by explicit and tacit knowledge. Explicit knowledge is codified as information and can be readily transmitted between individuals both formally and systematically. Tacit knowledge is on the other hand highly personal and hard to formalize, making it difficult to communicate or share with others [7, 4:395].

From these definitions we observe that KaaS would either provide codified (explicit) knowledge transfer to the client via online interface, or tacit knowledge transfer via face-to-face interface (such as professional consulting), or via telephone interface (such as call center or help desk service by human agents). For the purposes of this paper, KaaS service model is analyzed in the context of grid-network-based services - i.e. codified knowledge provisioning.

The on-demand knowledge service types that could be offered by KaaS can be categorized representatively as:

- Explicit or codified knowledge which includes: (1) general information aggregation and retrieval open to public, (2) specialist routine knowledge retrieval ondemand, (3) specialized codified knowledge generated by trained service agents by performing pre-defined set of 
activities or processes for the clients on behalf of the firm to whom the KaaS provider is contracted for the service provision, (4) Specialist knowledge codified into software and provisioned as software as a service (SaaS) to which a client firm may be subscribed so as to add its own codified knowledge for use by its own internal customers (staff members).

- Tacit knowledge which includes: (1) specialized tacit knowledge service provided by an expert and (2) Professional consulting service - ad hoc by contract assignment.

The degree of 'work' that a client has to perform to integrate the 'knowledge' acquired from KaaS with its own internal knowledge and competences to co-create value varies with the KaaS service type - e.g. the client has to do much more to create value (e.g. new knowledge) with the information aggregation (Google-like) service than in the case of hiring a professional consultant to create the same new knowledge for the firm. The degree of customer involvement in value co-creation and in some cases KaaS knowledge coproduction is a central KaaS service design issue which directly impacts the pricing and revenue mechanisms. Client feedback in KaaS service is part of the client involvement design issue.

\section{BUSINESS MODEL \& SERVICE SCIENCE PRINCIPLES}

A commercially viable KaaS must comply with business model and service science principles.

Business model defines the manner by which an enterprise delivers value to customers, entices customers to pay for value, and converts those payments to profit [10]. Business model design [2] must articulate the value proposition (benefits to customers), identify the chosen market segment, define the structure of the value chain and resources/assets required to deliver on the value proposition, define the revenue mechanisms and associated cost structure for the offering, and position the focal firm in the value network with a competitive strategy that give it advantage over its rivals sustainably. Thus KaaS design must include its business strategic choices for resources and competences, organizational structure, propositions for value delivery.

A service-centered view of KaaS is inherently customeroriented and relational [12]. Service is a process of applying the provider's competence (i.e. knowledge and skills) for the benefit of, and in conjunction with, the customer. A service offering is produced using the provider's resources which include both tangible (such as computer systems) and intangible (such as knowledge, competence and relationship) assets. But the value characteristics of the service provisioned are co-created through the interactions of the client's competences (knowledge and skills) with that of the service provider; thus, the client is (pro-)active in service interaction and it co-creates value for itself with the provider [6]. Value co-creation interactions between provider and client (service) systems are service interactions. Each interaction is made up of three main activities [8]: (1) proposal - proposing a value- creation interaction to another service system (e.g. client); (2) agreement - agreeing to a proposal; and (3) realization realizing the proposal. And value co-creation consists of three contiguous processes: the customer value-creating processes; the provider value-creating processes; and the encounter processes through which the customer interacts with the provider [9].

From the above business model constructs, service science principles and the KaaS model in Figure 1, we propose a classification scheme for classifying the various types of KaaS in terms of the business model constructs as shown in TABLE I.

\section{Methodological FrameWORK FOR KAAS DESIGN}

Using the business model and service science principles, we propose a macro-framework for designing a commercially viable KaaS service methodically by going through the following steps iteratively while ensuring the criteria of each step are satisfied integratively (congruently) with the other steps:

a. the KaaS service fulfills an un-served or under-served market segment;

b. distinctive KaaS customer value proposition (benefits to the customers are superior to what's available or expected in the marketplace) which resonates with the firm's brand and corporate values;

c. pricing and revenue mechanisms are simple and reinforce the customer's sense of fairness in terms of KaaS value for money;

d. agile KaaS value network design of partners, suppliers and customer that delivers maximum value and minimal costs and fulfills the KaaS customer value proposition distinctly, and that can be readily reconfigured to sustain its superior value proposition, in response to the dynamic environmental (market and technology) changes;

e. continuous alignment and realignment of the customer, KaaS provider and encounter processes end-to-end to ensure lean production and lean consumption (which includes decision on the customer involvement strategies for knowledge co-production and value co-creation) of KaaS service so as to maximize customer experience in accordance with the rigorous service engineering principles [1];

f. integrate the revenue mechanisms seamlessly with the KaaS service delivery process to enhance the value-formoney service integrity and experience for the customer;

g. experiment with customers and quickly learn from feedback and redesign KaaS service model to match customers expectations;

h. incorporate unique KaaS design themes (strategy) to 'lock in' customers and 'lock out' current or future competitors;

i. sense and seize the opportunities to redesign/reconfigure and implement change to the KaaS business and service models in response to or in anticipation of external environmental (market, regulatory or technology) changes 


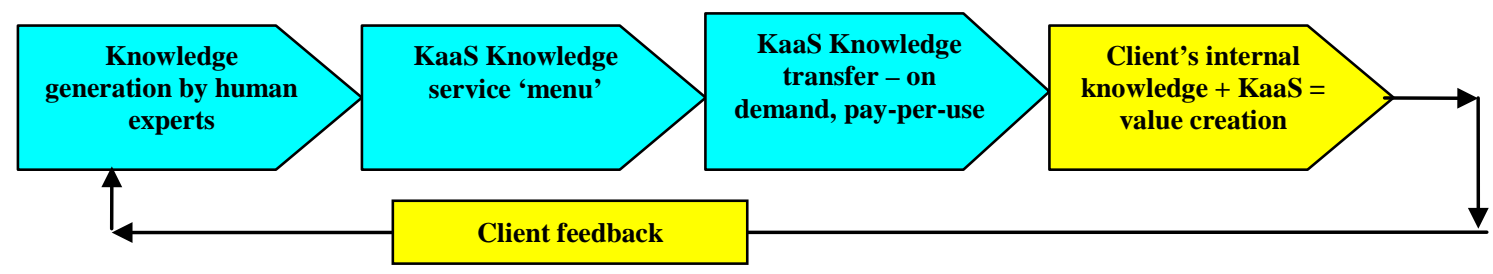

Figure 1. KaaS Service Model according to knowledge and service science theories

TABLE I. KAAS CLASSIFICATION SCHEME BASED ON BUSINESS MODEL PRINCIPLES

\begin{tabular}{|c|c|c|c|c|c|}
\hline KaaS Type & Value propositions & Revenue model & $\begin{array}{l}\text { Relationship with } \\
\text { client }\end{array}$ & $\begin{array}{l}\text { Network partners } \\
\text { / organization } \\
\text { structure }\end{array}$ & $\begin{array}{l}\text { Resources } \\
\text { competences }\end{array}$ \\
\hline $\begin{array}{l}\text { Information (codified } \\
\text { knowledge) retrieval } \\
\text { e.g. Google ; } \\
\text { Wikipedia }\end{array}$ & $\begin{array}{lr}\text { Information } & \text { on } \\
\text { demand - via } & \text { rapid } \\
\text { search } & \text { using } \\
\text { keywords - } & \text { sub- } \\
\text { second response time }\end{array}$ & $\begin{array}{l}\text { Advertisement; } \\
\text { sponsorship or } \\
\text { subscription }\end{array}$ & $\begin{array}{l}\text { Remote access via } \\
\text { online interface }\end{array}$ & $\begin{array}{l}\text { Worldwide hosts } \\
\text { containing } \\
\text { publicly accessible } \\
\text { information; } \\
\text { advertisers; wiki- } \\
\text { editor volunteers; }\end{array}$ & $\begin{array}{l}\text { specially-designed } \\
\text { computing } \\
\text { hardware \& } \\
\text { software } \\
\text { infrastructure }\end{array}$ \\
\hline $\begin{array}{lr}\begin{array}{l}\text { Routine } \\
\text { (codified) }\end{array} & \text { knowledge } \\
\text { ergieval } \\
\text { e.g. stock } \\
\text { intelligence }\end{array}$ & $\begin{array}{l}\text { Advice on demand - } \\
\text { via structured queries } \\
\text { or semi-natural } \\
\text { language }\end{array}$ & $\begin{array}{l}\text { Subscription } \quad \text { or } \\
\text { pay-per-use }\end{array}$ & $\begin{array}{l}\text { Remote access via } \\
\text { online interface; plus } \\
\text { help-desk ; account } \\
\text { management for } \\
\text { subscription } \\
\text { customers }\end{array}$ & $\begin{array}{lr}\text { Company } & \text { public } \\
\text { relations; } & \text { stock } \\
\text { analysts; } & \\
\text { regulators; } & \text { central } \\
\text { banks; } & \end{array}$ & $\begin{array}{l}\text { knowledge } \\
\text { management } \\
\text { software, e.g. } \\
\text { CRM software }\end{array}$ \\
\hline $\begin{array}{lr}\text { Knowledge } & \text { (codified } \\
\text { or tacit) produced via } \\
\text { predefined } \\
\text { activities } & \text { e.g. coutine } \\
\text { centre call } & \text { Business } \\
\text { Process Outsourcing; } & \text { credit check agency }\end{array}$ & $\begin{array}{ll}\text { Business outcome on } \\
\text { demand }- & \text { via } \\
\text { Contracted SLA } & \end{array}$ & $\begin{array}{l}\text { Task-based or } \\
\text { outcome-based } \\
\text { fixed term contract }\end{array}$ & $\begin{array}{l}\text { Remote access via } \\
\text { online or telephone } \\
\text { interface; plus help- } \\
\text { desk ; account } \\
\text { management for } \\
\text { subscription } \\
\text { customers }\end{array}$ & $\begin{array}{l}\text { Education } \\
\text { institutions; labor } \\
\text { recruitment } \\
\text { agencies; } \\
\text { computer and } \\
\text { software vendors; } \\
\text { telecom networks }\end{array}$ & $\begin{array}{l}\text { Trade-trained } \\
\text { human resources; } \\
\text { computer, } \\
\text { software } \\
\text { infrastructure }\end{array}$ \\
\hline $\begin{array}{l}\text { Knowledge (tacit) } \\
\text { produced via ad hoc } \\
\text { queries e.g. online tax } \\
\text { consultant or other } \\
\text { professional services } \\
\text { such as medical } \\
\text { imaging diagnosis }\end{array}$ & $\begin{array}{lr}\text { Specialist } & \text { task } \\
\text { performance } & \text { on } \\
\text { demand - via menu- } & \text { listed SLA per } \\
\text { service item } & \end{array}$ & $\begin{array}{l}\text { Pay-per-use or } \\
\text { fixed term contract }\end{array}$ & $\begin{array}{l}\text { Remote access via } \\
\text { online or telephone } \\
\text { interface; plus help- } \\
\text { desk ; account } \\
\text { management for } \\
\text { subscription } \\
\text { customers }\end{array}$ & $\begin{array}{l}\text { Other consultants; } \\
\text { professional } \\
\text { associations; } \\
\text { medical imaging } \\
\text { vendors }\end{array}$ & $\begin{array}{l}\text { combination of } \\
\text { expert systems and } \\
\text { human experts }\end{array}$ \\
\hline $\begin{array}{l}\text { Professional services } \\
\text { consulting invoked by } \\
\text { ad hoc requests (tacit } \\
\text { knowledge) }\end{array}$ & $\begin{array}{l}\text { Advanced advisory } \\
\text { services }\end{array}$ & $\begin{array}{l}\text { Pay-per-use or } \\
\text { fixed term contract } \\
\text { per assignment }\end{array}$ & $\begin{array}{l}\text { On-site working with } \\
\text { clients; back-office } \\
\text { analysis; account } \\
\text { management }\end{array}$ & $\begin{array}{l}\text { Complementary } \\
\text { consultants; } \\
\text { education } \\
\text { institutions; } \\
\text { professional } \\
\text { associations; } \\
\text { business councils }\end{array}$ & $\begin{array}{l}\text { Specialist } \\
\text { professionals with } \\
\text { accredited } \\
\text { qualifications }\end{array}$ \\
\hline $\begin{array}{l}\text { Software as a service - } \\
\text { specialist knowledge } \\
\text { embedded in the } \\
\text { software, } \\
\text { technique } \\
\text { managing customer } \\
\text { relationship embedded } \\
\text { in Salesforce's CRM } \\
\text { SaaS, to which clients } \\
\text { can add their own } \\
\text { customer specific } \\
\text { information }\end{array}$ & \begin{tabular}{lr}
\multicolumn{2}{l}{ Specialist application } \\
customizable & to \\
client's & unique \\
requirements &
\end{tabular} & Subscription & $\begin{array}{l}\text { Online interface; } \\
\text { help-desk; account } \\
\text { management }\end{array}$ & $\begin{array}{l}\text { Complementary } \\
\text { software service } \\
\text { providers; clients' } \\
\text { information } \\
\text { systems }\end{array}$ & $\begin{array}{l}\text { Industry } \\
\text { specialists and } \\
\text { software designers } \\
\text { and programmers }\end{array}$ \\
\hline
\end{tabular}




\section{CONCLUSIONS}

The paper proposes a KaaS conceptual model (Figure 1) by using the well-known theory and definitions of knowledge visà-vis information. Based on this KaaS model, using the principles of business model and service science, the paper proposes a representative classification KaaS business model types (TABLE I); as well as a preliminary macromethodological framework for designing commercially viable KaaS. The design emphasis is on distinctive KaaS value proposition for a chosen market segment, simple revenue mechanism, low cost structure, and agile value network that position the focal firm strategically on the 'choke-point' in the value net which 'locks in' its customers and value partners while 'locking-out' potential or real competitors.

A cursory trial 'retrospective' application of the proposed methodology to a successful 'knowledge factory' service provider was performed. The firm provides a knowledge codification service (on a contract basis) by performing digitization of hand-written documents accurately, speedily and cost-effectively (to agreed Service Level Agreements) for its customers by using a combination of human- and technology-based service platform - a core competence the provider has been developing ('perfecting') over many years of experimentations (trial-and-error) with its customers and partners. It highlights the firm's competitive advantage transcends its service platform to include its network of customers and most importantly its channels to raw talents whom can be quickly trained, morphed and absorbed into the firm's core competency fabric of knowledge creation.

This is a preliminary macro-methodological framework for KaaS service design. More work still needs to be done to validate the framework comprehensively, and to refine it and to flesh it out with details by applying it systematically to a case study of real KaaS firm. This is being applied to the above-mentioned service provider.

\section{REFERENCES}

[1] Aurich, J. C., Mannweiler, C. and Schweitzer, E. (2010) How to design and offer services successfully, CIRP Journal of Manufacturing Science and Technology 2 136-143.

[2] Chesbrough, H. (2010), Business Model Innovation: Opportunities and Barriers, Long Range Planning 43 354363

[3] Chew, E. K. (2010), Service Science - A Reflection from Telecommunications Service Perspective, Chapter 16 in Maglio, P. P., Kieliszewski, C. A, and Spohrer, J. C. (Eds.) (2010), Handbook of Service Science, Springer New York.

[4] Chew, E. K. \& Gottschalk, P. (2009), Information Technology Strategy and Management: Best Practices, Information Science Reference, Hershey, New York

[5] Fahey, L and Prusak, L (1998). The Eleven Deadliest Sins of Knowledge Management. California Management Review, 40 (3), pp 265-276

[6] Gallouj, F. (2002), Innovation in services and the attendant old and new myths, Journal of Socio-Economics 31 137-154

[7] Grover, V and Davenport, TH (2001). General Perspectives on Knowledge Management: Fostering a Research Agenda. Journal of Management Information Systems, 18 (1), pp 5-21

[8] Maglio, P. P., Vargo, S. L., Caswell, N. and Spohrer, J. (2009), The service system is the basic abstraction of service science, Inf Syst E-Bus Manage 7:395-406

[9] Payne, A. F. \& Storbacka, K. \& Frow, P. (2008) Managing the co-creation of value, J. of the Acad. Mark. Sci. (2008) 36:83-96

[10] Teece, D. J. (2010), Business Models, Business Strategy and Innovation, Long Range Planning 43 172-194

[11] Vaquero, L. M., Rodero-Merino, L., Caceres, J., and Lindner, M. (2009), A Break in the Clouds: Towards a Cloud Definition, ACM SIGCOMM Computer Communication Review, Vol 39, No. 1, January, 50-55

[12] Vargo, S. L. and Lusch, R. F. (2008), Service-dominant logic: continuing the evolution, Journal of the Academy of Marketing Science, 36 (Spring), 1-10. 